\title{
Description of two new species of Malacoceros and Rhynchospio spionids (Polychaeta: Spionidae) from the Grand Caribbean region
}

\author{
Descripción de dos nuevas especies de espiónidos de Malacoceros y Rhynchospio \\ (Polychaeta: Spionidae) de la región del Gran Caribe
}

\section{HUGO DELGADO-BLAS ${ }^{1, ~ *} \&$ ÓSCAR DÍAZ-DÍAZ ${ }^{2}$}

\author{
${ }^{1}$ División de Ciencias e Ingeniería, Universidad de Quintana Roo, Departamento de Ingeniería, Boulevard Bahía s/n \\ Esq. Ignacio Comfort, Col. del Bosque, C. P. 77019, Chetumal, Quintana Roo, México \\ ${ }^{2}$ Instituto Oceanográfico de Venezuela, Universidad de Oriente, Sucre-Venezuela \\ *Corresponding author: blas@uqroo.mx
}

\begin{abstract}
Two new species of spionids are described from the Caribbean Sea, Malacoceros cariacoensis n. sp. from Venezuela and Rhynchospio harrisae n. sp. from Guana in the Virgin Islands, British Virgin Island. Malacoceros cariacoensis $\mathrm{n}$. sp. can be differentiated by the shape of the prostomium, which has two short frontal horns and the posterior portion laterally prolonged into a faintly demarcated, double-looped nuchal organ, extending to the base of setiger 2 , a reduction in the size of setiger 1 , the absence of body pigmentation, and the number of apical teeth on the hooded hooks. Rhynchospio harrisae n. sp. differs from other species of the genus in that the peristomium is moderately developed with low lateral wings, and the anterior notopodial setae are arranged in two rows with a superior tuft of capillaries. A key to Malacoceros species worldwide is provided.
\end{abstract}

Key words: Caribbean, Malacoceros, Rhynchospio, Spionidae, taxonomy.

\section{RESUMEN}

Se describen dos nuevas especies de espiónidos del mar Caribe, Malacoceros cariacoensis n. sp. de Venezuela y Rhynchospio harrisae n. sp. de Guana, Islas Vírgenes, Islas Vírgenes Británicas. Malacoceros cariacoensis n. sp. puede diferenciarse por la forma del prostomio, el cual posee dos cuernos frontales cortos, un par de órganos nucales se extienden hasta la base del setígero 2, setígero 1 reducido, pigmentación del cuerpo ausente, y en el número de dientes apicales de los ganchos cubiertos. Rhynchospio harrisae n. sp. difiere de las otras especies del género en que el peristomio está moderadamente desarrollado con pequeñas alas laterales, las setas anteriores notopodiales están arregladas en dos hileras y en la región superior con un mechón de setas capilares. Se proporciona una clave de especies de Malacoceros.

Palabras clave: Caribe, Malacoceros, Rhynchospio, Spionidae, taxonomía.

\section{INTRODUCTION}

The Spionidae Grube, 1850, is one of the major polychaete families, with well over 1,000 nominal species (Sigvaldadóttir et al. 1997). Spionids are widely distributed and well represented from the intertidal zone to deep waters on several types of substrate, although a few species have also been collected from fresh water ecosystems (Blake 1996, DelgadoBlas 2009).

An important number of species have been recorded to the region from Grand Caribbean by several investigations. Schmarda (1861) identified the first three spionid species from the Grand Caribbean as a result of several visits to the Caribbean islands. Augener (1927) described one species for Curaçao, Treadwell $(1939 a, 1939 b)$ recorded three species, Hartman (1951) reported the first collection of polychaetes off the coast of the Gulf of Mexico, including 12 previously identified spionid species, most of which represented new records, as well as the description of a new genus and three new species. Foster (1971) in his monograph on the fauna of the Gulf of Mexico and the Caribbean Sea, recorded 26 species in 16 genera, including four new species: Spio pettiboneae, Rhynchospio inflatus, Scolelepis texana and Prionospio cristata, and three new genera: Apoprionospio, Aquilaspio and Minuspio; Perkins \& Savage (1975) listed 
23 genera and 58 species, although several of the taxa identified were later synonymized with other spionid genera or belong to other families. Johnson (1984) recorded 29 species from soft substrates north of the Gulf of Mexico, with 11 new records and possibly five new species. Salazar Vallejo (1996) listed 49 spionid species and 22 genera for the Grand Caribbean region. Recently several new species of spionids have been described from the region of the Grand Caribbean: DelgadoBlas (2004) described two new species of Paraprionospio. This same author described two new species and reinstated four species: $S$. (S.) goodbodyi (Jones, 1962), S. (S.) minuta (Treadwell, 1939), S. (S.) acuta (Treadwell, 1914) and $S$. (S.) agilis (Verrill, 1873) in a partial revision of Scolelepis from the Grand Caribbean Region (Delgado-Blas 2006). Also, Delgado-Blas (2008) described five new species in four genera: Boccardia salazari, Dipolydora anatentaculata, D. contoyensis, Polydora quintanarooensis and Pseudopolydora floridensis. Finally, Delgado-Blas, Díaz Díaz \& Liñero-Arana (2009) described one new species: Scolelepis (Scolelepis) andradei.

Overall, 59 species in 25 genera have been recorded for the Grand Caribbean region, to date (Delgado-Blas 2009).

Malacoceros is a companion genus to Rhynchospio, having horns, but with the branchiae arising from setiger 1 instead of setiger 2 (Blake \& Kudenov 1978). Rhynchospio has been considered both as a separate genus in its own right (Hartman 1959, 1969, Day 1967, Fauchald 1977, Blake \& Kudenov 1978, Imajima 1991, Radashevsky 2007) and as a subgenus of Malacoceros (Pettibone 1963, Foster 1971b, Sikorsky 1994). Blake (1996), however, considered Malacoceros and Rhynchospio as a generic pair analogous to Dispio/Scolelepis and Spio/ Microspio in having branchiae arising from the first or second setiger, respectively. In this paper, Malacoceros and Rhynchospio are treated as distinct genera.

The most recent diagnosis of the genus Malacoceros Quatrefages, 1843 is given by Hourdez et al. (2006) as follows: characterized by having a protomium with frontal or laterofrontal horns, branchiae from setiger 1 to near the end or the end of the body, branchiae basally fused to dorsal lamella, with only capillary notosetae, neurosetae include capillaries, anterior scalpel setae often bearing an arista, hooded hooks uni-, bi, tri- or quadridentate and sabre setae, pygidium anal cirri. At present, Malacoceros is composed of nine recognized species: $M$. vulgaris (Johnston, 1827) from England; M. tetracerus (Schmarda, 1861) from France; M. fuliginosus (Claparède, 1868) from Italy; $M$. vanderhorsti (Augener, 1927) from Curaçao; M. indicus (Fauvel, 1928) from Gulf of Manaar, Indian Ocean; M. tripartitus Blake \& Kudenov, 1978 from Victoria, Australia; $M$. reductus Blake \& Kudenov, 1978 from New South Wales, Australia; M. samurai Hourdez, Desbruyères \& Laubier, 2006 from chimney walls of hidrotermal vents on the Routh East Pacific Rise; M. jennicus Graff, Blake \& Wishner 2008 from a submarine volcano in the Caribbean.

Rhynchospio Hartman, 1936 is characterized by having a prostomium with latero-frontal horns, a variously developed caruncle, branchiae arising from setiger 2 either free or fused basally with the notopodial lamellae, capillary notosetae and the pygidium with cirri or lobes. According to the revision of Rhynchospio by Radashevsky (2007) there are eight species: Rhynchospio arenincola Hartman, 1936 from California; R. australiana Blake \& Kudenov, 1978 from Australia; $R$. foliosa Imajima, 1991 from Japan; $R$. glycera Blake \& Kudenov, 1978 from Australia; $R$. glutaea (Ehlers, 1897) from Chile; $R$. inflatus (Foster, 1971a) from the Bahamas; $R$. tuberculata Imajima, 1991 from Japan; and $R$. nhatrangi Radashevsky, 2007 from Vietnam.

In this paper two new species of Spionidae are described: Malacoceros cariacoensis n. sp. from Venezuela and Rhynchospio harrisae $\mathrm{n}$. sp. from Guana in the Virgin Islands.

\section{METHODS}

Malacoceros specimens were collected from soft sea bottom sediments employing a PVC corer $\left(0.018 \mathrm{~m}^{2}\right)$, taking cores of $20 \mathrm{~cm}$ in depth which were then sieved using a $0.5 \mathrm{~mm}$ open mesh. Rhynchospio specimens were loaned by the Los Angeles County Museum of Natural History. Specimens were fixed in $10 \%$ formaldehyde and preserved in $70 \%$ ethanol. They were then examined using compound microscopes, and structures of taxonomic value were used for diagnostic purposes, such as the shape of prostomium and peristomium, the length of the caruncle, arrangement of eyes, first occurrence of sabre setae and hooded 
hooks, number of teeth on the hooks and the number of pygidial cirri. Drawings were made with a camera lucida. The material has been deposited in: the Allan Hancock Foundation Polychaete Collection at the Los Angeles County Museum of Natural History (LACMAHF POLY); the Laboratorio de Biología de Poliquetos, Universidad de Oriente, Venezuela (LBP); the Colegio de la Frontera Sur, Universidad Chetumal, Mexico (ECOSUR). In the text the number of specimens in a sample is given in brackets after the abbreviation for the museum.

\section{RESULTS}

\section{Systematics}

Spionidae Grube, 1850

Malacoceros Quatrefages, 1843

Type species: Malacoceros vulgaris (Johnston, 1827), designated by Pettibone, 1963.

\section{Key to Malacoceros species}

1 Prostomium with latero-frontal horns ........ 2

- Prostomium with lateral horns ...................... 4

2 Scalpel setae present in anterior neurosetae; hooded hooks unidentate; four anal cirri M. samurai

- Scalpel setae absent. 3

3 Hooded hooks tridentate; six anal cirri ...M. reductus

- Hooded hooks bidentate; four anal cirri.. $M$. jennicus

4 Caruncle trilobed; body with dark brown pigmentation; sabre setae present from setiger 25; six anal cirri .......... M. tripartitus

- Caruncle entire 5

5 Hooded hooks bidentate ................................ 6

- Hooded hooks tri- or quadridentate ............ 8

6 Body heavily pigmentated; bidentate hooded hooks present from setigers 3040 M. fuliginosus

- Body without pigmentation; bidentate hooded hooks present but from setigers other than 30-40 7

7 Bidentate hooded hooks present from setigers 52-60; anterior notopodial lamellae free from branchiae. ..$M$. cariacoensis $\mathrm{n}$. sp.

- Bidentate hooded hooks present from setigers 20-28; anterior notopodial lamellae fused to branchiae M. tetracerus

8 Hooded hooks tridentate; present from setigers 30-40; 15-30 anal cirri ... M. vulgaris

- Hooded hooks tri- and quadridentate
9 Hooded hooks present from setigers 30-50; four anal cirri M. indicus

- Hooded hooks present from setiger 70; two anal cirri M. vanderhorsti

Malacoceros cariacoensis n. sp. (Fig. 1A-O)

Type material: All type specimens from Turpialito, Venezuela were collected from soft sea bottoms near mangroves $\left(10^{\circ} 26^{\prime} 21^{\prime \prime} \mathrm{N}\right.$; 62 02'11” W), $1.5 \mathrm{~m}$, coll. O. Díaz Díaz: holotype (LACM-AHF POLY 2241), 22 Feb 2002; 3 paratypes (ECOSUR-100), 22 Feb 2002; 10 paratypes (LBP-0050), 12 Nov 2007.

Description: Holotype an incomplete anterior fragment; $20 \mathrm{~mm}$ long, $1.5 \mathrm{~mm}$ wide excluding setae, with 121 setigers. Color in alcohol: pale tan.

Prostomium bell-shaped and short lateral horns (Fig. 1A); prostomium extending anteriorly beyond peristomium, caruncle triangular reaching up to anterior margin of setiger 2, surrounded laterally by 2 nuchal organs extending posteriorly to setiger 2 (Fig. 1A). Occipital antenna absent. Seven small brown eyespots present, arranged in a transverse row. Peristomium not developed into lateral wings or hood, separate from setiger 1 (Fig. 1B). Eversible proboscis, saclike (Fig. 1B). Palps lost.

Branchiae from setiger 1 free basally to notopodial lamellae; all branchiae cirriform, relatively narrow, tapering to blunt tip, and longer than the lamellae, at least up to end of the fragment (Fig. 1C).

Parapodia of setigers 1-2 shifted dorsally with well-developed dorsal and ventral postsetal lamellae (Fig. 1B). Anterior and middle notopodial postsetal lamellae triangular with pointed tips (Figs. 1E-G), decreasing in size in posterior setigers; anterior notopodial presetal lamellae small, on setigers 11-47 well developed, rounded, ventrally fused with postsetal lamellae (Fig. 1I) so that they appear to form a closed sheath or covering, low and lobed on remaining segments (up to the end of the fragment).

Neuropodial postsetal lamellae foliaceous on setigers 1-3 (Figs. 1D-1E), lamellae rounded from setiger 4 onwards (Figs. 1F-G and 1I), largest in anterior setigers, as a low lobe on posterior setigers. 

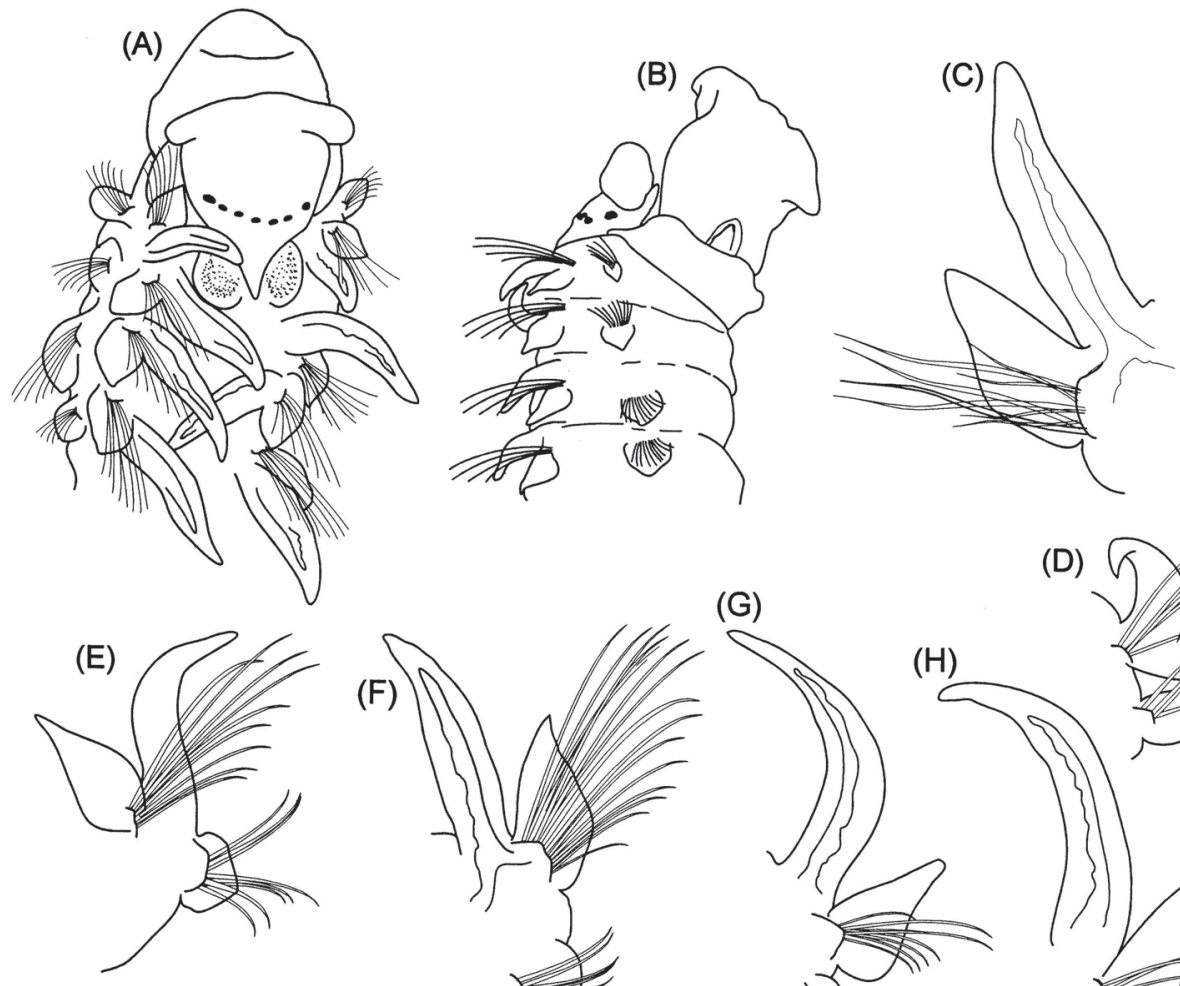

(F)
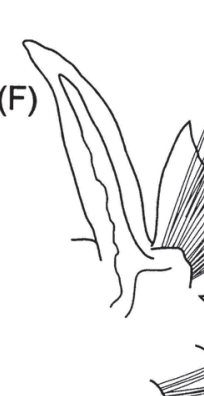

(G)

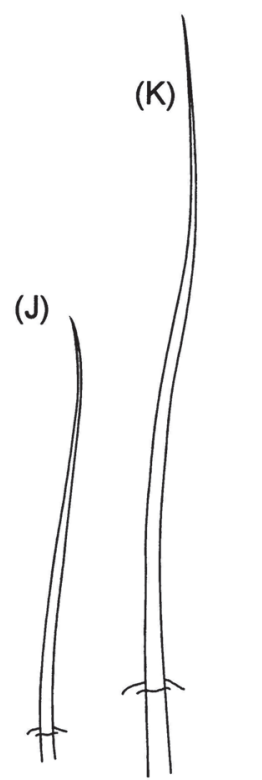

(L)

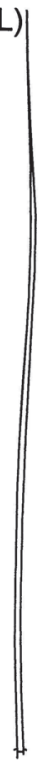

(O)
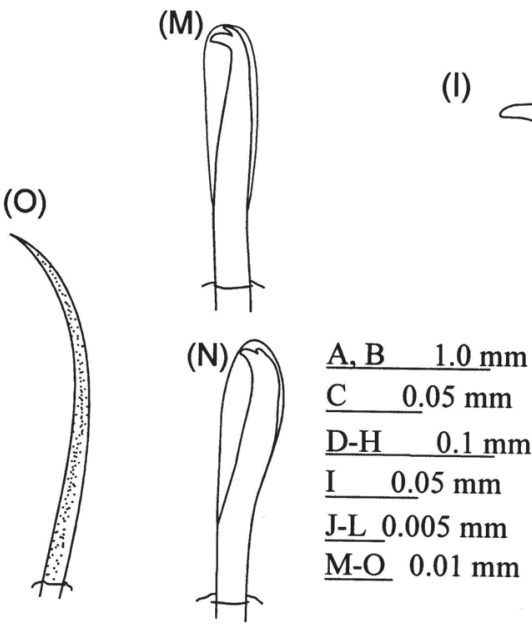

(D)

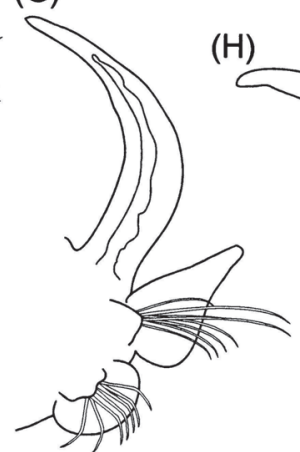

(1)

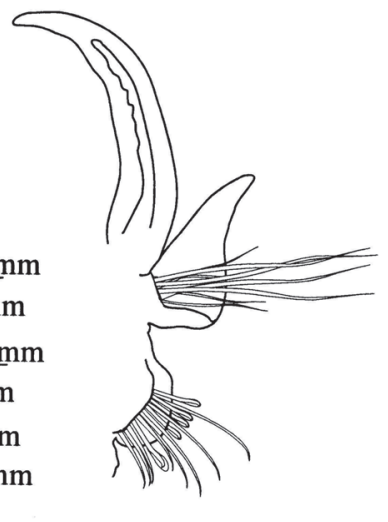

Fig. 1: Malacoceros cariacoensis n. sp.: (A) anterior end, dorsal view (holotype); (B) same in lateral view; (C) branchia and notopodium of middle setiger; (D) parapodium of setiger 1; (E) parapodium of setiger 3; (F) parapodium of setiger 4; $(\mathrm{G})$ parapodium of setiger 20; $(\mathrm{H})$ parapodium of setiger 57; (I) parapodium of middle setiger; $(\mathrm{J})$ short capillary notoseta; (K) long capillary notoseta; (L) companion neuroseta; (M-N) bidentate neuropodial hooded hooks; (O) sabre seta. Scale bars = (A-B) $1.0 \mathrm{~mm}$; (C) $0.05 \mathrm{~mm}$; (D-H) $0.1 \mathrm{~mm}$; (I) $0.05 \mathrm{~mm}$; (J-L) $0.005 \mathrm{~mm}$; (M-O) $0.01 \mathrm{~mm}$.

Malacoceros cariacoensis n. sp.: (A) región anterior, vista dorsal (holotipo); (B) región anterior, vista lateral; (C) branquia y notópodo de setígero medio; (D) parápodo de setígero 1; (E) parápodo del setígero 3; (F) parápodo del setígero 4; (G) parápodo del setígero 20; $(\mathrm{H})$ parápodo del setígero 57; (I) parápodo de setígero medio; (J) notoseta capilar corta; (K) notoseta capilar larga; (L) neuroseta acompañante; (M-N) ganchos cubiertos neuropodiales bidentados; (O) seta sabre. Barra de escalas = (A-B) $1.0 \mathrm{~mm}$; (C) $0.05 \mathrm{~mm}$; (D-H) $0.1 \mathrm{~mm}$; (I) $0.05 \mathrm{~mm}$; (J-L) $0.005 \mathrm{~mm}$; (M-O) $0.01 \mathrm{~mm}$. 
Anterior noto- and neuropodial setae all capillary, arranged in two rows. Notopodial setae of anterior row short (Fig. 1J), posterior row longer (Fig. 1K), both rows of setae lacking granulations and sheaths. Posterior setigers with capillaries thin, granulation and limbation absent (Fig. 1L). Neuropodial hooded hooks bidentate (Fig. 1M), from setiger 60, numbering up to seven per fascicle; hooks accompanied by capillaries throughout; some bidentate hooded hooks with upper tooth small (Fig. 1N). Sabre setae from setiger 5, numbering 4-5 per fascicle, heavily granulated, limbation absent (Fig. 10). Pygidium unknown.

Variability: All specimens are anterior fragments $10-32 \mathrm{~mm}$ long, $1.2-1.5 \mathrm{~mm}$ wide, with $67-130$ setigers. Four to seven eyes in a row, except for one specimen with two irregular clusters of 6-8 small eyespots and one without eyes. A double-looped nuchal organ was observed on two specimens. Neuropodial hooded hooks from setigers 5760 . One specimen with neuropodial hooded hooks from setiger 52, up to seven per fascicle.

Remarks: Malacoceros cariacoensis $\mathrm{n}$. sp. is very similar to $M$. tetracerus with respect to the shape of the prostomium and caruncle, the presence of bidentate hooks and the absence of body pigmentation. It differs by having hooded hooks from setigers 52-60, a doublelooped nuchal organ, and in having the anterior notopodial lamellae free of the branchiae. Malacoceros cariacoensis n. sp. is also similar to $M$. vanderhorsti in having pairs of eyes arranged into additional eyespots (every group with 7 small brown eyes), and the parapodia of setigers 1-2 shifted dorsally with well-developed dorsal and ventral postsetal lamellae, a poorly developed peristomium and no lateral wings. Malacoceros cariacoensis n. sp. differs from $M$. vanderhorsti, however, by the two shorter prostomial frontal horns, the absence of body pigmentation, the number of teeth on the hooded hooks, the lateral prolongation of the posterior portion of the prostomium into a faintly demarcated, double-looped nuchal organ extending to the base of setiger 2 , and the reduction of setiger 1. Differences between $M$. cariacoensis n. sp. and other species in the genus are detailed in the key.
Habitat: Specimens collected from soft bottoms near mangroves, the sediment with predominance of fine material and $8 \%$ of content of organic matter.

Distribution: Turpialito, Venezuela.

Etymology: Species named after the locality where they were collected: Turpialito in the Cariaco Gulf, Venezuela.

\section{Rhynchospio Hartman 1936}

Type species: $R$. arenicola Hartman 1936, by monotypy.

\section{Rhynchospio harrisae n. sp. (Fig. 2A-N)}

Type material: Mexico: Holotype, Mahahual, Quintana Roo, (1842’39” N; 87²4'33” W), 25 February 2001, (LACM-AHF POLY 2231), coll. L. Harris, LH01-519, collected among turf algae in shallow water; British Virgin Islands: 3 paratypes, Trellis Bay, Beef Island 12 July 2000 (18²6’42” N; 64³1'59” W), (LACM-AHF POLY 2240), coll. L. Harris, Vc0705; 8 paratypes, White Bay, Guana Island, 4 July 2000, (18 28'27” N; 64 34'29” W), (LACM-AHF POLY 2236), coll. L. Harris, Vc0068, collected among fine turf algae on coral rubble or pebbles in very shallow water; 5 paratypes, White Bay, Guana Island, 4 July 2000, $\left(18^{\circ} 28^{\prime} 27^{\prime \prime} \mathrm{N} ; 64^{\circ} 34^{\prime} 29^{\prime \prime} \mathrm{W}\right)$, (LACM-AHF POLY 2235), coll. L. Harris, Vc0008, collected among fine turf algae on coral rubble or pebbles in very shallow water; 1 paratype, North Bay, Guana Island, 14 July 2000, $\left(18^{\circ} 28^{\prime} 48^{\prime \prime} \mathrm{N} ; 64^{\circ} 34^{\prime} 23^{\prime \prime} \mathrm{W}\right)$, (LACM-AHF POLY 2237), coll. L. Harris, Vc0869, collected among fine turf algae on coral rubble or pebbles in very shallow water; 1 paratype, Long Point Guana Island, 5 July 2000, $\left(18^{\circ} 27^{\prime} 28^{\prime \prime} \mathrm{N} ; 64^{\circ} 45^{\prime} 01^{\prime \prime} \mathrm{W}\right)$, (LACM-AHF POLY 2239), coll. L. Harris, Vc0960, collected among fine turf algae on coral rubble or pebbles in very shallow water; 3 paratypes, Long Point, Guana Island, 5 July 2000, $\left(18^{\circ} 27^{\prime} 28^{\prime \prime} \mathrm{N} ; 64^{\circ} 45^{\prime} 01^{\prime \prime} \mathrm{W}\right)$, (LACM-AHF POLY 2239), coll. L. Harris, Vc0958, collected among fine turf algae on coral rubble or pebbles in very shallow water .

Description: Holotype complete, $5 \mathrm{~mm}$ long, $0.6 \mathrm{~mm}$ wide excluding setae, with 32 setigers. Color in alcohol: opaque white. Oocytes present between setigers 12-16. 

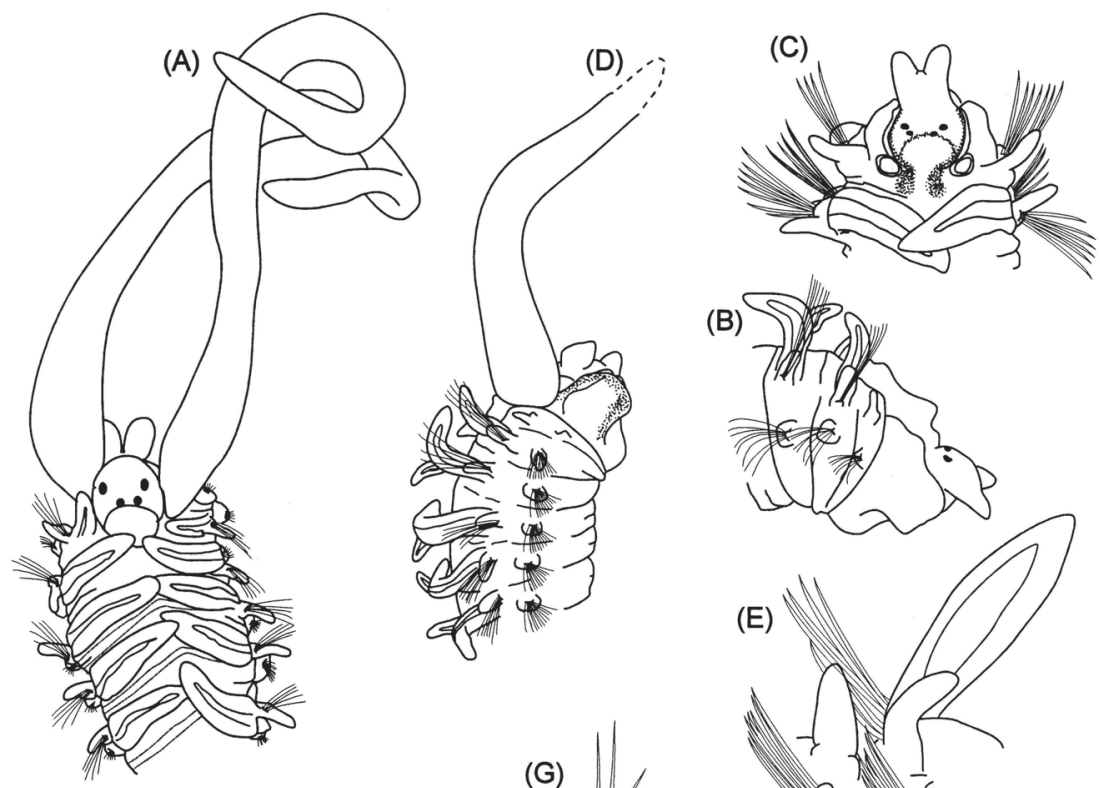

(B)
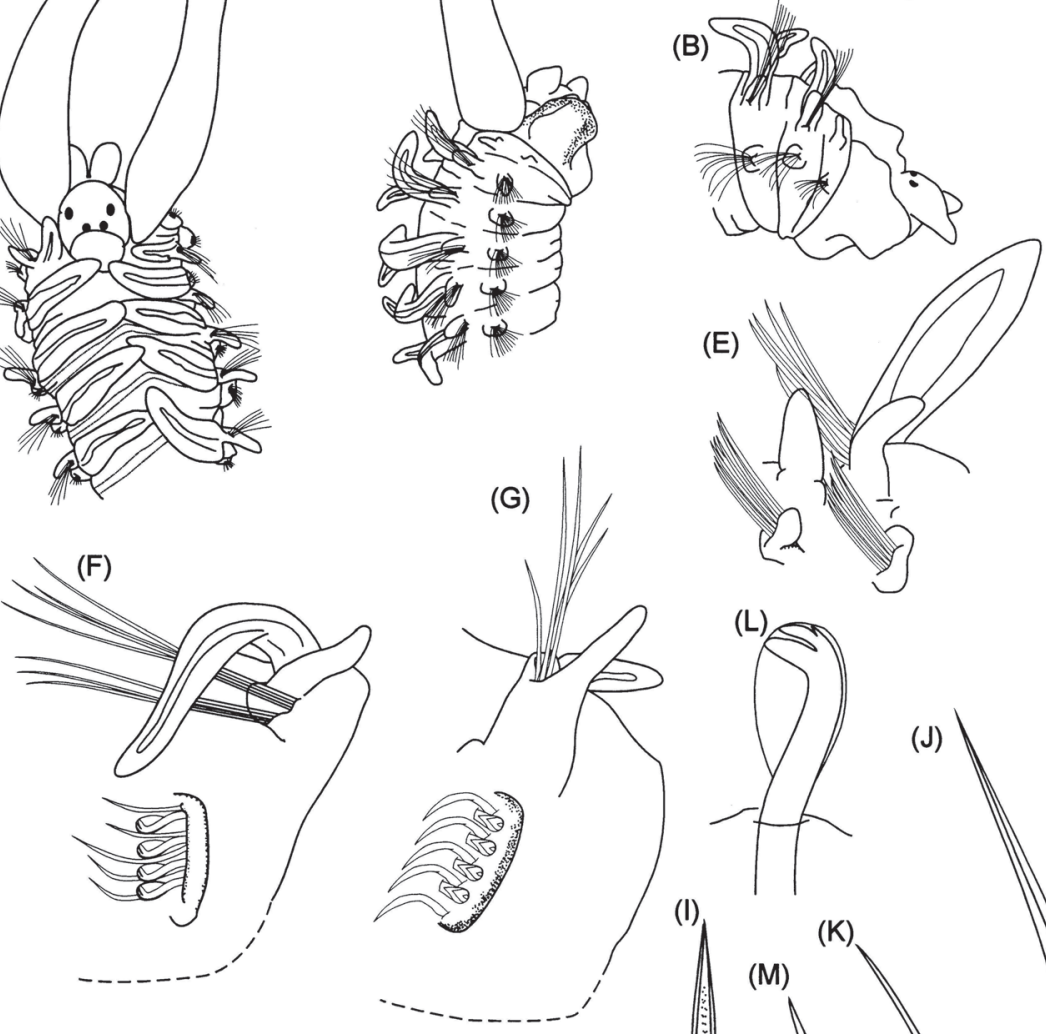

(E)
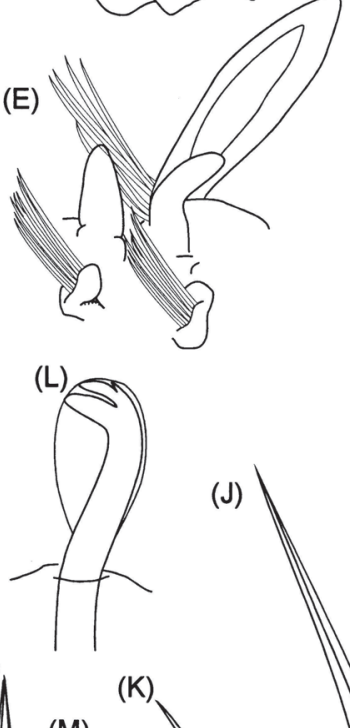

\section{(J)}
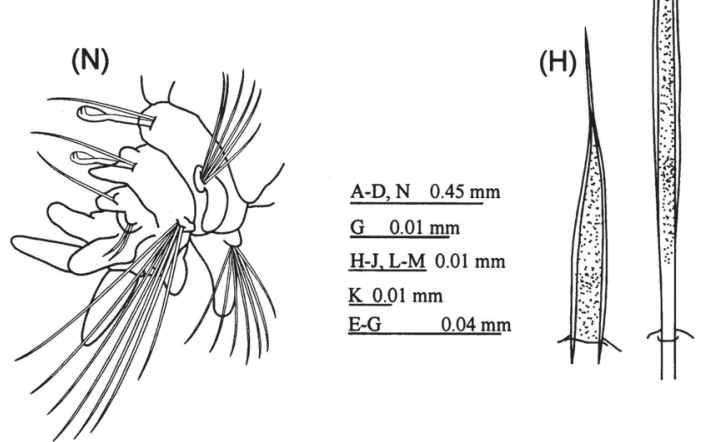

(M)

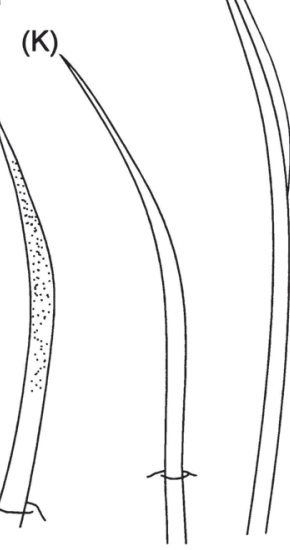

Fig. 2: Rhynchospio harrisae n. sp. (A) anterior end, dorsal view (holotype); (B) anterior end, lateral view (paratype); (C) anterior end, dorsal view (paratype); (D) anterior end, lateral view (holotype); (E) setigers 1 and 2; (F) parapodium of setiger 10; (G) parapodium of setiger 27; (H) capillary notoseta; (I) capillary notoseta from superior tuft; (J) posterior neuropodial capillary seta; (K) neuropodial companion seta; (L) hooded hook; (M) sabre seta; $(\mathrm{N})$ pygidium and posterior most setigers, dorsolateral view. Scale bars = $(\mathrm{A}-\mathrm{C}$, M) $0.45 \mathrm{~mm}$; (G-H) $0.01 \mathrm{~mm}$; (I-L) $0.01 \mathrm{~mm}$; (K) $0.01 \mathrm{~mm}$; (D) $0.025 \mathrm{~mm}$; (E-F) $0.04 \mathrm{~mm}$.

Rhynchospio harrisae n. sp. (A) región anterior, vista dorsal (holotipo); (B) región anterior, vista lateral (paratipo); (C) región anterior, vista dorsal (paratipo); (D) región anterior, vista lateral (holotipo); (E) setígero 1 y 2; (F) parápodo del setígero 10; (G) parápodo del setígero 27; (H) notoseta capilar; (I) notoseta capilar del mechón superior; (J) neuroseta capilar posterior; (K) neuroseta acompañante; (L) gancho cubierto; $(\mathrm{M})$ seta sabre; (N) pigidio y setígeros posteriores, vista dorso lateral. Barra de escalas $=(\mathrm{A}-\mathrm{C}, \mathrm{M}) 0.45 \mathrm{~mm}$; (G-H) $0.01 \mathrm{~mm}$; (I-L) $0.01 \mathrm{~mm}$; (K) $0.01 \mathrm{~mm}$; (D) $0.025 \mathrm{~mm}$; (E-F) $0.04 \mathrm{~mm}$. 
Prostomium bell-shaped and bearing two conspicuous, rounded frontal horns (Fig. 2A); caruncle emerging posteriorly with a prominent occipital lobe (Figs. 2A-B) bearing a drop-shaped pair of nuchal organs arising from a common base up to the anterior margin of setiger 2 (Fig. 2C). Two pairs of rounded eyes, arranged in a trapezoid pattern, anterior pair larger and spaced; posterior pair small and rounded. Peristomium moderately developed, forming low lateral wings (Fig. 2D). Palps basally wide, insert dorsally on the peristomium, extending posteriorly to setiger 10; palps with longitudinal groove lined with fine frontal cilia. Palp sheaths absent.

Dorsally, all segments have transverse ciliary band, composed of two rows of cilia (Fig. 2A).

Setiger 1 reduced, but with small notopodial lamellae, lacking notosetae (Fig. 2E); neuropodial lamellae oval, larger than notopodial lamellae, and capillary neurosetae arranged in one row. All notopodial lamellae digitiform (Figs. 2E-G). All neuropodial lamellae rounded, middle lamellae wider (Fig. $2 \mathrm{G})$.

Anterior notopodial setae arranged in two rows and with a superior tuft of capillaries; both rows with capillaries distally pointed, slightly granulated (Fig. 2H); 3-9 setae of superior tuft distally pointed, lanceolate, slightly granulated and longer (Fig. 2I); middle and posterior setigers with one row of capillaries similar to the anterior setae.

Setiger 1 with capillary neurosetae arranged in one row; from setiger 2 onwards setae arranged in two rows with an inferior tuft of four capillaries; both rows of setae similar to notosetae, posterior row longer; posterior neuropodia with capillary setae very long and unilimbated (Fig. 2J). Low presetal lamellae present in both rami on anterior setigers.

Neuropodial hooded hooks tridentate from setiger 8 , numbering up to six per fascicle; hooks accompanied by 3-8 alternating capillaries throughout (Fig. $2 \mathrm{~K}$ ); hooks with an inconspicuous tooth inserted above more prominent apical tooth (Fig. 2L). Sabre setae curved appearing as a gradual transformation of the inferior capillaries on setiger 13, numbering up to two per fascicle, slightly granulated and alimbate (Fig. 2M).
Branchiae from setiger 2, long and thick. Widest basally, not fused to notopodial lamellae, continuing near to posterior end of body, absent from four posterior most setigers; all branchiae flattened, with inner margins ciliated; longer from setigers 3-7, overlapping middorsally (Fig. 2A).

Pygidium with two ventral lappets and two dorsal cirri (Fig. 2N), the former shorter than cirri.

Variability: All types 2-11 mm long, 0.3-0.7 $\mathrm{mm}$ wide, with low lateral peristomial wings. Complete specimens with 23-37 setigers, one specimen with dorsal pygidial cirri three times longer than ventral lappets, two specimens with subequal cirri. Two to eight sabre setae arising from setigers 12-13. Neuropodial hooded hooks from setigers $8-9$, up to five per fascicle, accompanied with 1-2 capillary setae. Nuchal organs reaching second setiger. Two specimens with two pairs of eyes arranged in a transversal row, and one with three pairs arranged in a triangle, the anterior pair very small and some specimens with anterior pair reniform. Palps extending posteriorly to setigers $6-14$. The holotype mature with oocytes in setigers 5-20, this region being swollen.

Remarks: Rhynchospio harrisae n. $\mathrm{sp}$. is most similar to $R$. australiana in that setiger 1 lacks notopodial capillaries and has neuropodial hooks from setiger 8. However, $R$. harrisae n. sp. differs from $R$. australiana in the shape of the prostomium ( $R$. harrisae has two frontal horns), the absence of vesiculated sheaths on the anterior capillary setae and the shape of the pygidium. $R$. harrisae differs from $R$. inflatus (Foster 1971a) in the shape of the caruncle, the lenght of the peristomium, by lacking notosetae on setiger 1 , absence interparapodial pouches, and the number of apical teeth in hooded hooks. Rhynchospio harrisae n. sp. differs from the other species in the genus in that the peristomium is moderately developed, forming lateral wings, the anterior notopodial setae are arranged in two rows with a superior tuft of capillaries, an inconspicuous third tooth on the hooded hooks, and the shape of the pygidium.

Habitat: Specimens collected were associated with algae and sand, in shallow waters.

Distribution: Caribbean: Mahahual, Quintana Roo, Guana (Virgin Is.). 
Etymology: This species is dedicated to Leslie Harris for her important work at the Los Angeles County Museum of Natural History, Allan-Hancock Foundation and her great knowledge of polychaete taxonomy.

\section{ACKNOWLEDGMENTS}

This study was generously supported by the Division de Ciencias e Ingeniería of the Universidad de Quintana Roo, México and the Instituto Oceanográfico de Venezuela-Universidad de Oriente. Leslie Harris (LACM-AHF) loaned some important materials to be identified. The comments of Danny Eibye-Jacobsen (ZMUC) and two anonymous reviewers improved the manuscript.

\section{LITERATURE CITED}

AUGENER H (1927) Polychaeten Von Curaçao. Bijdragen tot de Dierkunde Amsterdam 25: 3982

BLAKE JA (1996) Family Spionidae Grube, 1850. In: Blake JA, B Hilbing \& PH Scott (eds) Taxonomic atlas of the benthic fauna of the Santa Maria Basin and the Western Santa Barbara Channel. Vol. 6 The Annelida, Part 3: 81-223. Polychaeta: Orbiniidae to Cossuridae. Santa Bárbara Museum Natural of History, Santa Barbara, California.

BLAKE JA \& JD KUDENOV (1978) The Spionidae (Polychaeta) from southeastern Australia and adjacent areas, with a revision of the genera. Memoirs of the National Museum of Victoria 39: $171-280$.

DAY JH (1967) A monograph on the Polychaeta of southern Africa. Part I. Errantia; Part II. Sedentaria. Trustees of the British Museum of Natural History, London, UK.

DELGADO-BLAS VH (2004) Two new species of Paraprionospio (Polychaeta: Spionidae) from the Grand Caribbean region and comments of the genus status. Hydrobiologia 520: 189-198.

DELGADO-BLAS VH (2006) Partial revision of Scolelepis (Polychaeta: Spionidae) from the Grand Caribbean Region, with the description of two new species and a key to species recorded in the area. Contributions to Zoology 75: 75-97.

DELGADO-BLAS VH (2008) Polydora and related genera (Polychaeta: Spionidae) from the Grand Caribbean region. Journal of Natural History 42: $1-19$.

DELGADO-BLAS VH (2009) Spionidae Grube, 1850. En: de León-González JA, R Bastida-Zavala, LF Carrera-Parra, P Hernández-Alcántara, SI Salazar-Vallejo \& V Solís-Weiss (Comps) Poliquetos (Annelida: Polychaeta) de México: Generalidades y claves para identificación de especies 3: 589-614.

DELGADO-BLAS VH, OF DÍAZ-DÍAZ \& I LIÑEROARANA (2009) New record and new species of Scolelepis (Polychaeta: Spionidae) from the Venezuelan Caribbean. Journal of the Marine Biological Association of the United Kingdom: 1-5.
FAUCHALD K (1977) The polychaete worms. Definitions and keys to the orders, families, and genera. Natural History Museum of Los Angeles County, Science Series 28: 1-188.

FAUVEL P (1928) Annelides polychetes nouvelles de l'Indie. Bulletin du Muséum d'Histoire Naturelle (Paris) 34: 90-96.

FOSTER N (1971a) Spionidae (Polychaeta) of the Gulf of Mexico and the Caribbean Sea. Studies on the fauna of Curacao and other Caribbean islands 37: $1-138$

FOSTER N (1971b) Redescription of the spionid polychaete Malacoceros (Malacoceros) indicus (Fauvel, 1928). Journal of the Fisheries Research Board of Canada 28: 1455-1457.

GRAFF JR, JA BLAKE \& KF WISHNER (2008) A new species of Malacoceros (Polychaeta: Spionidae) from Kick'em Jenny, a hydrothermally active submarine volcano in the Lesser Antilles Arc. Journal of the Marine Biological Association of the United Kingdom 88: 925-930.

GRUBE AE (1850) Die familien der anneliden. Archiv für Naturgeschichte (Berlin) 16: 249-364.

HARTMAN O (1936) New species of Spionidae (Annelida: Polychaeta) from the coast of California. University of California Publications in Zoology 41: 45-52.

HARTMAN O (1951) The littoral marine annelids of the Gulf of Mexico. Publications of the Texas University. Institute of Marine Science 2: 7-124.

HARTMAN O (1959) Catalogue of the polychaetous annelids of the world. Allan Hancock Foundation Occasional Paper 23: 1-628.

HARTMAN O (1969) Atlas of the sedentariate polychaetous annelids from California. Allan Hancock Foundation, University of Southern California, Los Angeles.

HOURDEZ S, D DESBRUYĖRES \& L LAUBIER (2006) Malacoceros samurai, a new species of Spionidae (Annelida: Polychaeta) from hydrothermal vent chimney walls on the South East Pacific Rise. Proceeding of the Biological Society of Washington 119: 592-599.

IMAJIMA M (1991) Spionidae (Annelida, Polychaeta) from Japan VI. The genera Malacoceros and Rhynchospio. Bulletin of the National Sciences Museum Zoology (Japan) 17: 5-17.

JOHNSTON G (1827) Contributions to the British fauna. Zoological Journal of the London 3: 321336.

JOHNSON PG (1984) Spionidae. In: Uebelacker JM \& PG Johnson (eds) Taxonomic guide to the polychaetes of the Northern Gulf of México: 6.1 6.69. Barry A. Vittor y Assoc., Mobile, Alabama.

KEFERSTEIN W (1862) Untersuchungen iiber niedere Seethiere. Zeitschrift für Wissenschaftliche Zoologie, McIntosh 12: 1-147.

PERKINS TH \& T SAVAGE (1975) A bibliography and checklist of polychaetous annelids of Florida, the Gulf of Mexico, and the Caribbean Region. Florida Marine Research Publications 14: 1-62.

PETTIBONE MH (1963) Revision of some genera of polychaete worms of the family Spionidae, including the description of a new species of Scolelepis. Proceedings of the Biological Society of Washington 76: 89-104

QUATREFAGES A de (1843) Description de quelques especes nouvelles d'Annelides errantes recueillies sur les cotes de la Manche. Magasin de Zoologie Paris 2: 1-16. 
RADASHEVSKY VI (2007) Morphology and biology of a new Rhynchospio species (Annelida: Spionidae) from the South China Sea, Vietnam, with the review of Rhynchospio taxa. Journal of Natural History 41: 985-997.

RATHKE H (1837) Zur Fauna de Krym. Memoires de L'Academie Nauk SSSR, Leningrad 3: 291-454.

SALAZAR-VALLEJO SI (1996) Bibliografía y lista de especies de poliquetos (Polychaeta) del Gran Caribe. Anales del Instituto de Biología UNAM Zoología (Mexico) 43: 11-52.

SCHMARDA LK (1861) Neue wirbellose Thiere beobachtet und gesammelt auf einer Reise um die Erde 1853 bis 1857. Leipzig, Vol. 1. Turbellarien, Rotatorien und Anneliden Pt. 2, 1164.

SIGVALDADÓTTIR E, ASY MACKIE \& F PLEIJEL (1997) Generic interrelationships within the Spionidae (Annelida: Polychaeta). Zoological Journal of the Linnean Society 119: 473-500.

Associate Editor: Mario George-Nascimento

Received May 7, 2009; accepted November 31, 2009
SIKORSKY AV (1994) Malacoceros (Polychaeta, Spionidae) in the Artic Ocean. Zoologischeskii Zhurnal 73: 21-35. (Russian with English summary)

TREADWELL AJ (1939a) New polychaetous annelids from New England, Texas and Puerto Rico. American Museum Novitates 1023: 1-7.

TREADWELL AL (1939b) Polychaetous annelids of Porto Rico and vicinity. NY Academy of Sciences Survey Porto Rico Virgin Islands 16: 150-319.

USCHAKOV PV (1948) On two new species of Scolelepis (Spionidae, Polychaeta) from Murmansk Coast. Trudy Murmansk Biologial Station Akademia Nauk SSSR 1: 284-285.

WILLIAMS JD (2007) New records and description of four new species of spionids (Annelida: Polychaeta: Spionidae) from the Philippines: The genera Dispio, Malacoceros, Polydora, and Scolelepis, with notes on palp ciliation patterns of the genus Scolelepis. Zootaxa 1459: 1-35. 
